\title{
REFORMASI AGRARIA DALAM PERSPEKTIF PERLINDUNGAN LINGKUNGAN HIDUP
}

\author{
Samsul Wahidin \\ Fakultas Hukum Universitas Merdeka Malang \\ Jl. Terusan Dieng No. 62-64; Malang; 65146; Indonesia; (0341) 580161 \\ swahidin@yahoo.com
}

\begin{abstract}
The aggregate sector is one of the most complex social issues. This is in line with population growth and the need for natural resources, especially land. The settlement of Agraria disputes to seek legal certainty which has long been untouchable for the settlement of the problem. While the solution to the problem tends to keep pace with the ongoing changes. The solution tends to be temporary. In the case of a solid foundation as a basis for completion, not only for the present but for the future. As a result of these limitations, the various rules that exist and serve as the basis of the law are lagging behind by the reality of society. A far-reaching orientation is from an environmental perspective. As a result of these limitations to this orientation, environmental issues tend to be ignored. Here, the urgency of structuring must start from the beginning, with emphasis on the mindset of the community on the problem of aggregation, in the perspective of lasting environmental protection. It takes a synergy between the question of aggregation on the one hand and the need for an environmentbased management orientation on the other side.
\end{abstract}

Keywords: Environmental, Legal Protection, National Indigenous.

\begin{abstract}
Abstrak
Sektor keagrariaan merupakan satu di antara permasalahan sosial yang sangat kompleks. Hal ini sejalan dengan pertumbuhan penduduk dan kebutuhan terhadap sumber daya alam khususnya pertanahan. Penyelesaian sengketa agraia untuk mencari kepastian hukum dimana sudah sejak lama tidak tersentuh untuk penyelesaian permasalahanya. Sementara penyelesaian terhadap permasalahan tersebut cenderung berpacu dengan perubahan yang terus berlangsung. Penyelesaiannya cenderung besifat temporer. Pada hal harusnya ada dasar yang kokoh sebagai basis penyelesaian, tidak semata untuk saat sekarang tetapi untuk masa yang akan datang. Akibat keterbatasan ini, berbagai peraturan yang ada dan dijadikan sebagai dasar hukum tertinggal oleh kenyataan yang ada dalam masyarakat. Orientasi yang jauh daeri jangkauan adalah dalam perspektif lingkungan hidup. Akibat dari keterbatasan terhadap orientasi ini, permasalahan lingkungan hidup cenderung diabaikan. Di sini, urgensinya penataan yang harus dimulai dari awal, dengan menitikberatkan pada pola pikir masyarakat terhadap problema keagrariaan, dalam perspektif perlindungan lingkungan hidup yang langgeng. Dibutuhkan sineregitas antara masalah keagrariaan pada satu sisi dengan keharusan orientasi pengelolaan yang berbasis lingkungan hidup pada sisi lain.
\end{abstract}

Kata Kunci:Keagrariaan Nasional, Lingkungan Hidup, Perlindungan Hukum. 


\section{Reformasi Agraria dalam Perspektif Perlindungan Lingkungan Hidup}

Samsul Wahidin

Bahasa sederhana, mencari dan menemukan kekeliruan dan kesalahan dalam menghadapi permasalahan itu jauh lebih mudah daripada menemukan kebaikan atau aspek positifnya. Demikian pula dalam hal keagrariaan nasional ini. Membuat sebuah pemahaman sederhana bahwa telah terjadi kesalahan bahwa untuk membangun suatu yang dasar tidak menempatkan pembangunan baru tentang pertanahan yang berbentuk pengaturan ulang penguasaan pembangunan, peruntukan, pemanfaatan serta pemeliharaan sumber-sumber pertanagan sebagai kondisi sebelum pembangunan (pokok masalah agraria) (Siregar, 2012).

Perlu kiranya dipahami kembali bahwa pembaruan Agraria menurut Siregar (2012)adalah proses perbaikan dan pengolahan lagi struktur masyarakat, utamanya masyarakat desa. Jadi dasarnya bukan pada permasalahan pertanahan semata. Segera dinyatakan bahwa dengan tindakan ini idealismenya adalah terciptanya dasar pengelolaan tanah yang baik, mendapatkan kepastian hukum atas tanah bagi masyarakat sebagai mata pencarian mereka, oleh karena itu perlu suatu sistem yang meningkatkan kesejahteraan dan penjaminan sosial untuk rmasyarakat perdesaan, jaminan meningkatkan pengelolaan sumber daya alam guna kemakmuran sebesar-sebesarnya untuk kepentingan rakyat. (Siregar, 2012). Tegasnya, permasalahan pembangunan ini adalah pada manusianya.

Pandangan kesejarahan, disadari bahwa selama kurun waktu yang panjang terjadi kemelut pertanahan di Indonesia. Kemelut yang pada gilirannya tidak semata membuat ruwet permasalahan pertanahan tetapi juga cara berpikir dan cara pandang masyarakat terhadap permasalahan pertanahan ini.Inilah makna dari Reformasi Agraria. Memberikan dan mencari solusi konkret untuk memecahkan kemelut dimaksud.

Segera dapat dipahami, bahwa sejatinya Reformasi yang harusnya dilakukan adalah pada cara berpikir tentang masalah pertanahan. Bukan pada pertanahannya, atau pengaturannya itu sendiri. Dengan ReformasiAgraria, sedapat mungkin akan tertata pola pikir masyarakat tentang masalah pertanahan. Perobahan yang tentunya diarahkan kepda nilai yang lebih positif. Pola pikir inidimulai dari orang orang di lingkungan pemangku kepentingan dan penguasanya, yang diharapkan menjadi contoh bagi masyarakat.

\section{Proses Reformasi Agraria di Indonesia}

Pembaharuan Agraria (Agraria Reform/ Land Reform) kerap kali dianggap mempunyai pengertian sama. Pengertian dari reformasi reform sendiri berbagai pihak menyampaikan sudut pandang yang tidak sama tentang pembaharuan agraria ini. Menurut arti sempit pembaharuan agraria dipandang sebagai suatu redistribusi pertanahan, dengan suatu program yaitu pembagian pertanahan (redistribusi pertanahan) (Siregar, 2012). Hal tersebut hanya merupakan satu sisi kendatipun diakui sangat penting dalam ReformasiAgraria. Secara sempit diartikan dengan pendistribusian lahan berupa tanah semata (Poerwadarminta, 2006).

Pemahaman secara konseptual, bahwa menata kembali suatu status kepemilikan serta penguasaan tanah beserta paket penunjang lengkap merupakan suatu pengertian dari reformasiagraria. Paket penunjang disini adalah ada suatu jaminan kepastian atas hak yang dimiliki dan diberikan, tersedianya kredit yang tejangkau, adanya akses terhadap jasa-jasa advokasi, akses terhadap infomasi baru dan tekhnologi, Pendidikan dan latihan, serta adanya akses terhadap segala macam prasarana dan sarana produksi sampai dengan pemasaran (Siregar, 2012). Jadi tidak semata berdasarkan problematika pertanahan dalam arti sempit atau distribusi tanah.

Ada yang menyebut bahwa Reformasi Agraria juga dikenal sebagai pembaruan Agraria. Konsep pembaruan merujuk kepada pelaksanan- 
nya bahwa yang dimaksudkan lebih luas dari sekadar pembagian tanah atau pendistribusian tanah yang seringkali dipolitisasi itu. Oleh karena itu untuk menghindari pemahaman sempit mengenai reformasiagraria perlu dipahami kembali bahwa reformasiagraria tidak merupakan suatu proyek bagi-bagi tanah semata. Namun demikian dapat dipahami bahwa upaya meningkatkan kesejahteraan sosial pada khususnya masyarakat yang berkepentingan di desa keseluruhan. Selain sebagai upaya meningkatkan tata kelola pertanahan untuk menjamin kepastian hukum bagi masyarakat melalui sumber agraria(Siregar, 2012).

Pembaharuan agraria harus melibatkan berbagai pihak dalam memberikan jaminan. Bentuknya adalah memberikan sebidang tanah yang di berikan dan dapat dikembangkan serta produktif dan berkesinambungan prosesnya. Hal tersebut meliputi pemenuhan terhadap hak yang mendasar bagi petani dalam arti luas. intinya meningkatkan kesejahteraan khususnya petani. Pemenuhan hak mendasar ini dapat berupa pendidikan, kesehatan, dan tersedianya dukungan modal, tekhnologi, manajemen, infrastuktur pasar serta segala sesuatu yang tujuannya meningkatkan kesejahteraan khususnya petani

Hubungannya dengan hal di atas, ada dua komponen mendasar. Komponen yang pertama disebut sebagai asset reform, sedangkan yang kedua disebut access reform. Gabungan antara kedua jenis reform inilah yang dimaksud dengan land reformplus (Basya, 2012). Haltersebut menjadi inti dari pembaharuan pertanahan idealismenya adalah konsep yang betujuan tidak saja menata permasalahan lahan, tetapi juga kepada pola pikir masyarakat terhadap masalah pertanahan.

Seiring dengan ini, bahwa Reformasi Agraria yang dikualifikasi sebagai land reform plus dimaksud filosofinya berlandaskan Pancasila dan konstitusionalnya. Hal tersebut mengandung arti bahwa land reform digunakan untuk menata kembali suatu sistem yang selama ini tidak adil dengan suatu upaya menambak akses pembaharuan yang diorientasikan secara teknis kepada pengelolaan, yaitu berupa pemberian tanah bagi petani.

Tujuannya adalah sebagai sarana ataualat yang dapat memberikan manfaat dalam meningkatkan produktivitas sosialnya. Prinsip inilah yang digunakan sebagai pedoman dasar dalam pembaharuan agraria yang diemban reformasiagraria yaitu penataan tanah yang mencerminkan rasa adil dan mensejahterakan rakyat, khususnya petani dalam hal kepemilikan tanah sebagai penopang hidupnya.

Atas dasar pemikiran diatas digunakan sebagai pengertian reformasiagrariayang digunakan untuk penyelenggaraan di Indonesia, diuraikan berikut (Siregar, 2012):

1. Menurut Istilah TAP MPR IX/MPR/2001, bahwa Reformasi Agraria adalah restrukturisasi penggunaan, pemanfaatan, penguasaan dan pemilikan sumbersumber Agraria, terutama tanah yang mampu menjamin keadilan dan keberlanjutan peningkatan kesejahteraan rakyat.

2. Menurut Penjelasan Undang-Undang Republik Indonesia Nomor 5 Tahun 1960 tentang Pokok Agraria (UUPA) Pasal 10 Ayat 1 dan 2, bahwa: "land reform"atau "Agraria reform" yaitu sebagai suatu ketentuan bahwa tanah harus dikerjakan atau diusahakan secara aktif oleh pemiliknya sendiri. Selanjutnya ketentuan itu perlu diikuti pula dengan syarat-syarat yang ringan, sehingga pemiliknya tidak akan terpaksa bekerja dalam lapangan lain, dengan menyerahkan penguasaan tanahnya kepada orang lain.

Pemahaman pelaksanaan pembaharuan agraia sebagai langkah penguasa untuk menyelesaikan sengketa-sengketa selama ini tentang pertanahan, dengan melakukan pola kinerja yang sedara substantiftertuju pokok pangkal permasalahan, sebagai berikut (Siregar, 2012):

1. Sesuai dengan Undang-Undang Dasar Republik Indonesia Tahun 1945 dan Undang-Undang Republik Indonesia Nomor 5 Tahun 1960 tentang Pokok 


\section{Reformasi Agraria dalam Perspektif Perlindungan Lingkungan Hidup}

Samsul Wahidin

Dasar Agraria sebagai dasar pelaksanaan reformasi agraria dengan proses menata kembali sistem politik dan hukum pertanahan yang dilakukan oleh pemerinta;

2. Reformasi agraria merupakan satu kesatuan dengan land reform sebagai pendukung proses berjalannya land reform dan Access Reform (AR) secara bersama; $L R$ adalah proses redistribusi tanah untuk menata penguasaan, pemilikan, penggunaan dan pemanfaatan tanah berdasarkan politik dan hukum pertanahan. AR adalah suatu proses penyediaan akses bagi masyarakat (subjek ReformasiAgraria) terhadap segala hal yang memungkinkan masyarakat untuk mengembangkan tanahnya sebagai sumber kehidupan (partisipasi ekonomi- politik, modal, pasar, teknologi, pendampingan, peningkatan kapasitas dan kemampuan).

Komponen dasar sebagai operasionalisasi reformasi agraria adalah sebagai berikut (Siregar, 2012):

a. Pembagian tanah adalah supaya memberikan jaminan hak masyarakat atas sumber-sumber agraria (aset reform).

b. perkembangan pembangunan sebagai upaya meningkatkan produktif dan bekelanjutan, hal ini disebut akses form yang mencangkup antara lain pemenuhan hak dasar dalam arti luas sepeti kesehatan, dan pendidikan, juga penyedia dukungan modal, teknologi, manajemen, infrastruktur, pasar dan lain sebagainya.

Pengertian terhadap pembaharuan reformasi agrariasebagaimana dimaksud dalam beberapa komponen mendasar di dalamnya yang secara konsptual diurai sebagai permasalahan mendasar dari masalah keagrariaan nasional. Kelima hal dimaksud adalah (Risnarto, 2007):

a. restrukturisasi penguasaan aset tanah ke arah penciptaan struktur sosial-ekonomi dan politik yang lebih berkeadilan (equity),

b. sumber peningkatan kesejahteraan yang berbasis keagrariaan (welfare); c. penggunaan/pemanfaatan tanah dan faktor-faktor produksi lainnya secara optimal (efficiency);

d. keberlanjutan (sustanability), dan

e. penyelesaian sengketa tanah (harmony).

Tataran konseptual, dengan memerinci lebih lanjut terhadap batas kategori pembaharuan agraria adalah (Risnarto, 2007):

1. Radical Land reform, tanah milik tuan tanah yang luas diambil alih oleh pemerintah, dan selanjutnya dibagikan kepada petani tidak bertanah.

2. Land restitution, tanah - tanah perkebunan luas yang berasal dari tanah - tanah masyarakat diambil alih oleh pemerintah, kemudian tanah tersebut dikembalikan kepada pemilik asal dengan kompensasi.

3. Land Colonization, pembukaan dan pengembangan daerah - daerah baru, kemudian penduduk dari daerah yang padat penduduknya dipindahkan ke daerah baru tersebut, dan diberi tanah dengan luasan tertentu.

4. Market Based land reform (market assisted land reform), land reform yang dilaksanakan berdasarkan atau dengan bantuan mekanisme pasar.

\section{Tujuan Reformasi Agraria}

Institusi teknis yang bertanggung jawab terhadap pelaksanaan ReformasiAgraria adalah penguasa administratif pertanahan. Badan Pertanahan Nasional (BPN) merupakan badan pemerintah yang menajadi operator penyelenggaraan administrasi pertanahan di Indonesia. BPN berperan secara administratif berpedoman pada prinsip pertanahan yang memberikan pengaruh besar dalam mewujudkan kesejahteraan masyarakat; menata kehidupan masyarakat berdasarkan keadilan; warga Negara Indonesia, serta mencerminkan harmonisasi (teratasinya segala sengketa dan permasalahan pertanahan) (BPN, 2007).

Upaya mencapai tujuan BPN (2007) menetapkan 11 agenda pertanahan yang meliputi: 
1. Membangun kepercayaan masyarakat pada Badan Pertanahan Nasional RI;

2. Meningkatkan pelayanan dan pelaksanaan pendaftaran tanah serta sertifikasi tanah secara menyeluruh di Seluruh Indonesia;

3. Memastikan penguatan hak -hak rakyat atas tanah;

4. Menyelesaikan persoalan pertanahan di daerahdaerah korban bencana alam dan daerahdaerah konflik di seluruh tanah air;

5. Menangani dan menyelesaikan perkara, masalah, sengketa, dan konflik pertanahan secara sistematis;

6. Membangun Sistem Informasi Manajemen Pertanahan Nasional dan sistem pengamanan dokumen pertanahan di Seluruh Indonesia;

7. Menangani masalah Kolusi, Korupsi, Nepotisme (KKN) serta meningkatkan partisipasi dan pemberdayaan masyarakat;

8. Membangun basis data penguasaan dan pemilikan tanah skala besar;

9. Melaksanakan secara konsisten semua peraturan perundang-undangan pertanahan yang telah ditetapkan;

10. Menata kelembagaan Badan Pertanahan Nasional RI;

11. Mengembangkan dan memperbarui politik, hukum, dan kebijakan pertanahan (Reformasi Agraria).

Berdasarkan tujuan diatas BPN menetapkan tujuan utama dari terlaksananya pembaharuan pertanahan yaitu (BPN, 2007):

a. Menata kembali ketimpangan struktur penguasaan dan penggunaan tanah ke arah yang lebih adil;

b. Mengurangi kemiskinan;

c. Menciptakan lapangan kerja;

d. Memperbaiki akses rakyat kepada sumber-sumber ekonomi terutama tanah;

e. mengurangi sengketa dan konflik pertanahan;

f. Memperbaiki dan menjaga kualitas lingkungan hidup dan meningkatkan ketahanan pangan.

\section{Mekanisme Reformasi Agraria}

Reformasi agraria memiliki mekanisme dasar (Sumardjono, 2014), sesuai dengan kondisi atau kedudukan subyek (petani miskin, buruh tani, atau pengelola tanah) dan obyek (tanah yang akan diredistribusikan), sebagaimana dapat dicermati pada dokumen Badan Pertanahan nasional Republik Indonesia Tahun (2007) sebagai berikut:

1. Subyek dan objek berdekatan atau berhimpit, mekanisme dengan skenario seperti ini sebenarnya relatif lebih sederhana dan langsung fokus pada ketiga objek tanah dalam Reformasi Agraria ini, yaitu:

a. tanah kelebihan maksimum;

b. tanah absentee; dan

c. tanah negara lainnya, termasuk tanah tumbuh.

Penyelenggaraan ReformasiAgraria dalam skenario ini dapat ditempuh melalui penataan asset atau meredistribusi subjek tanah di atas, serta penguatan akses atau memperbaiki akses petani kepada teknologi baru, mendekatkan pelaku usaha dengan sumber-sumber pembiayaan, serta menyediakan akses pasar dan pemasaran bagi produk yang akan dikembangkan oleh subjek ReformasiAgraria.

2. Subjek mendekati objek. Mekanisme seperti ini diterapkan apabila subjek dan objek berada pada lokasi yang berjauhan. Skema transmigrasi umum dan transmigrasi lokal seperti dengan memindahkan subjek petani miskin dan tidak bertanah dari daerah padat penduduk ke daerah jarang penduduk, serta memberikan atau meredistribusikan tanah seluas dua hektar atau lebih di daerah tujuan kepada subjek Reformasi Agraria.

3. Objek mendekati subjek. Mekanisme seperti ini juga diterapkan apabila subjek dan objek berada pada lokasi yang berjauhan. Skema yang sesuai untuk mendekatkan objek kepada subjek dikenal dengan skema swap atau pertukaran tanah yang didasarkan pada strategi 


\section{Reformasi Agraria dalam Perspektif Perlindungan Lingkungan Hidup}

Samsul Wahidin

konsolidasi lahan atau bahkan bank tanah. Skema ini memang agak rumit karena melibatkan hubungan kepemilikan tanah bertingkat yang tidak sederhana, sehingga perlu dirumuskan secara hati- hati, dengan kelembagaan yang jelas dan berwibawa.

\section{Prinsip-prinsip Reformasi Agraria}

Secara garis besar, sebagaimana dapat dicermati pada dokumen resmi dari pemerintah (dalam hal inipihak departemen terkait), terdapat prinsip dalam Pembaruan Agraria. Prinsip dimaksud adalah sebagai berikut:

1. Menjunjung Tinggi Hak Asasi Manusia. Bahwa di dalam kaitan ini. berdasarkan Pasal 69 Ayat 2 Undang-Undang Republik Indonesia Tahun 1999 tentang Hak Asasi Manusia (UU HAM), hak atas sumber daya alam merupakan hak dasar ekonomi setiap warga negara, suatu yang menjadi hak setiap warga negara, merupakan kewajiban/ tanggung jawab bagi negara/ pemerintah untuk melindungi, memajukan, menegakkan, dan memenuhinya.

Permasalahan mendasar yang memerlukan klarifikasi dimaksud yakni (Harsono, 1961):

a. Negara "menguasai" sumber daya alam, maka siapa yang sebenarnya berhak atas sumber daya alam itu secara konkret.

b. Apakah makna di balik konsep "dikuasai" negara.

c. Seberapa luas kewenangan menguasai oleh negara dalam potensi sumber daya alam yang ada di dalam wilayah negara.

d. Bagaimana hubungan antar negara sebagai institusi yang mempunyai kekuasaan atas sumber daya alam, khususnya keagrariaan Pasal 33 Ayat 3 dalam penjelasannya menjelaskan dengan singkat, kaitannya dengan permasalahan ini harus diberikan pengertian luas melalui undang-undang yang terkait dengan sumber daya alam, konkretnya tanah, hutan, tambang, dan sebagainya. dengan demikian telah terjadi sesuatu yang mengenyampingkan hak-hak masyarakat lokal/adat atas sumber daya kaena terjadi "negaraisasi semua aset sumber daya alam dikuasasi tanpa memperhatikan kemanfaatan dan kesejahteraan masyarakat lokal/adat.

Proses "negaraisasi" tersebut dapat kita lihat dalam penjelasan UU PAtentang kekuasaan negara terhadap bumi, air, ruang angkasa, dalam kaitan ini efek dari "negaraisasi" atau hak kekuasaan tersebut terkait bumi yang diatasnya hak individu warga terkait tanah tersebut dan terdapat kewenangan ulayat, hak masyarakat adat dan tanah-tanah diatasnya tidak disebutkan sebagaimana disebutkan.

Analog proses "negaraisasi" jika diorientasikan berdasarkanUndang-Undang Republik Indonesia Nomor41 Tahun 1999 tentang Kehutanan) dengan segala peraturan pelaksanaannya khususnya hak menguasai negara atas hutan (hutan negara) maka hal itu berarti meliputi kawasan hutan di seluruh Indonesia.

Dengan demikian makna yang terkandung di dalam konseptualisasi Pasal 33 Ayat 3 adalah (Wahidin, 2014):

a. Bahwasanya Sumber Daya Alam merupakan hak bersama seluruh rakyat, dan dalam pengertian hak bersama itu terdapat dua hak yang diakui, yaitu hak kelompok (hak bersama) dan hak perorangan.

b. Bahwa kewenangan negara terhadap sumber daya alam terbatas pada kewenangan pengaturan. Bukan kewenangan kepemilikan atau pembatasan. Pengaturan oleh negara diperlukan karena adanya kekhawatiran bahwa tanpa campur tangan negara akan muncul ketidak adilan dalam akses terhadap perolehan dan pemanfaatan sumber daya alam oleh masyarakat.

c. Bahwasanya negara tidak perlu melakukan intervensi bila masyarakat telah dapat menyelesaikan masalah atau kepentingan 
sendiri dan bahwa hal itu tidak bertentangan dengan kepentingan atau hak pihak lain yang diproteksi secara konstitusional.

d. Bahwasanya kewenangan mengatur oleh negara tidak tak terbatas, tetapi dibatasi oleh dua hal, yaitu: (1) pembatasan oleh Undang-Undang Dasar (UUD). Pada prinsipnya hal-hal yang diatur oleh negara tidak boleh berakibat terhadap pelanggaran hak-hak dasar manusia yang dijamin oleh UUD; (2) pembatasan oleh tujuannya, yakni untuk sebesar-besar kemakmuran rakyat atau untuk tercapainya keadilan sosial.

Hubungan antara negara dengan rakyat bukan hubungan subordinasi. Namun demikian sebagai ikatan negara adalah milik rakyat yang diberi mandat untuk menguasai menduduki sebagai wakil dari rakyat. Hal ini sejalan dengan eksistensi Negara yang keberadaannya adalah utuk kesejahetraan rakyat. Negara dalam menjalankan mandat rakyat harus netral dan memberikan rasa keadilan ketikadiwujudkan pada tataran konkret.

2. Pluralisme dan Hukum Adat Ditampung dalam Unifikasi Hukum.

Pasal 6 Ayat (1) UU HAM. Dinyatakan oleh undang undang tersebut bahwa untuk penegakan hak asasi manusia, harus memberikan keistimewaan dan perhatian kepada masyarakat adat serta melindunginya oleh semua pihak (masyarakat, hukum, pemerintah).

Permasalahan di atas, dihubungkan dengan permasalahan keagrariaan ini adalah mempertimbangkan kembali keberadaan hukum adat dan masyarakat adat dalam pembaharuan pertanahan ini, karena pada prinsipnya pembaharuan ini bersifat nasional tetapi tidak meninggalkan masyarakat dan hukum yang tumbuh dan dijunjung tinggi dalam masyarakat. Oleh karena itu, hal tersebut tercermin dalam menjunjung tinggi nilai Hak Asasi manusia dan penegakannya sehingga dalam pelaksanaan tidak menimbulkan konflik sosial terhadap hak asasi manusia dan bertentangan dengan konstitusi.

3. Land Reform/Restrukturisasi Pemilikan dan Penguasaan Tanah.

Bahwa hakekatnya restrukturisasi pertanahan adalah merupakan cara penguasa untuk mengatur kembali tata kelola pertanahan nasional guna memberikan rasa keadilan dan kepastian kepada masyarakat. Hal ini khususnya ditujukan kepada warga masyarakat mata pencarian hidupnya bergantung dari hasil bumi misalkan petanidan di kawasan perkebunan sangat bergantung pada bidang tanah yang dimiliki.

Progam untuk merestrukturisasi pertanahan nasional sudah digerakan pemerintah sejak lama, misalkan redistribusi pertanahan berupa tanah yang berasal dari pejabat desa, tanah tidak sesuai kebutuhan riil perusahaan bidang industri, perumahan, jasa/ pariwisata, pengusaha di bidang pertanian, perkebunan dan kehutanan dan lain-lain (Wahidin, 2016). Tujuannya adalah peningkatan kesejahteraan sesuai komitmen konstitusi dan sebagai penyetaraan dan pengembangan dunia usaha dibidang pertanian dan memajukaan pertanian serta membuka pintu pemasaran untuk produk pertanian.

Urban land reformhendaknya mendapatkan perhatian selainrural land reform tersebut di atas. Hal ini disebabkan adanya terdapat perbedaan kemampuan antara masyarakat kelas atas dengan masyarakat kelas kurang mampu dalam memiliki sebidang tanah di pemukiman perkotaan dimana masyarakat kota kelas atas yang cenderung memiliki akses politik dan kekuasaan akan cenderung diuntungkan daripada masyarakat kelas kurang mampu. Sebagai akibatnya adalah munculnya kondisi masyarakat kelas kurang mampu dan generasi akan datang akan kesulitan dalam mendapatkan sebidang tanah untuk tempat tinggal dan men- 


\section{Reformasi Agraria dalam Perspektif Perlindungan Lingkungan Hidup}

Samsul Wahidin

cari penghasilan dari dunia pertanian karena kesulitan lahan yang dikuasai orang kelas atas.

4. Keadilan dalam Pengusaan dan Pemanfaatan Sumber-Sumber Agraria

Bahwa secara konstitusional untuk dalam rangka menjaga sumber daya alam untuk generasi akan datang dibutukan penguasaan dan pemanfaatan sumber daya alam pada kendali agar sumber daya alam ini tidak habis dimasa sekarang. Oleh karena itu segala bentuk hal positif harus diwariskan kepada generasi masa akan datang yang berkelanjutan terkait penguasaan dan pemanfaatan sumber daya alam (sumber Agraria). Pentingnya menjaga sumberdaya alam ini tidak habis dan berkelanjutan merupakan tantangan dan suatu permasalahan yang harus diselesaikan bersama.

Berdasarkan uraian di atas bahwa perlu dipahami bersama terkait penghematan sumber daya alam untuk generasi masa akan datang. Oleh karena itu ada komietmen yang harus dilaksanakan secara konsisten tidak mengeksploitasi untuk pemenuhan generasi sekarang secara berlebihan sehingga memperpendek usia sumber daya alam. Berkaitan dengan hal tersebut perluadanya pengakuan terhadaphak ulayat masyarakat adat agar keberlangsungan sumber daya alam tetap terjaga karena sumber daya alam yang hidup disekitar masyarakat adat adalah ruang hidupnya.

Oleh karena itu secara konstitusional untuk pengambilalihan hak itu harus dilaksanakan sesuai dengan aturan hukum yang menjadi dasarnya. Akomodasi hal ini adalah sebagaimana dinyatakan di dalam Pasal $28 \mathrm{H}$ Ayat (4) jo Pasal 28 J Ayat (2) UUD 1945 hasil Perubahan Kedua. berkaitan dengan hal tersebut bahwa setiap kerugian yang ditimbulkan dilindungi oleh hukum untuk mendapatkan jaminan ganti rugi dan kompensasi adil dari kerugiaan yang diderita secara fisik maupun semua kerugian nonfisik.
Menyelesaikan sengketa tanahharusnya diselesaikan secara bersamaan dan tuntas melingkupi segala aspek. Jika tidak dengan cara demikian dipastikan menjadi potensi konflik berkepanjangan. Hal ini adalah konflik sosial yang mengganggu ketertiban sosial masyarakat yang justru sulit diselesaikan.

5. Transparansi dan Partisipasi dalam Pembuatan Kebijakan.

Pembuatan kebijakan kedepan diaharapkan mendukung upaya pembaharuan pertanahan dengan lebih memberikan kewenangan dan penguasaan pertanahan ke daerah untuk di kelola dan dimanfaatkan daerah. Penyiapan Rancangan undang-undang dan rancangan peraturan pelaksanannya harus bersifat terbuka. Arti harus ada konsistensi untuk mendasarkan pada kebutuhan rakyat. Oleh karena itu harus senantiasa ada ruang untuk konsultasike masyarakat dalam setiap pembuatan kebijakan peraturan perundang-undangan dapat menampungperanserta dari stakeholders. Dengan demikian substansi yang terkandung dalam peraturan dimaksud jelas tujuan dan eksistensinya.

6. Pembiayaan Program-Program Pembaruan Agraria.

Reformasisi pertanahan membutuhkan program-program yang digunakan untk menyelesaikan permasalahan reformasi pertanahan. Terlaksananya program-program tersebutjuga dibutuhkan suatu rencana dan pembiayaan yang besar yang menjadi tanggung jawab pemerintah. Berkaitan dengan pelaksanaan program-program reformasi pertanahan harus didukung penuh dan berkelanjutan agar pelaksanaan program tersebut sesuai dengan tujuan. Oleh karena itu tersedianya dana yang memadai, dengan dukungan pengendalian secara sosial sangat dibutuhkan dan menjadi bagian dari pembiayaan secara konsisten. 
Faktor Penghambat dalam Reformasi Agraria di Indonesia

Sebagaimana dipahami bahwa untuk access reform merupakan suatu tahapan tersedianya akses bagi rakyat (subyek reformasi agraria) untuk memanfaatkan dan menguasai tanah sesuai dengan haknya sebagai sumber mata pencariaan (partisipasi ekonomi, politik, modal, pasa, teknologi, pendampingan, peningkatan kapasitas dan kemampuan). Hal ini juga tidak kalah mendasar dan beratnya untuk dilaksanakan bersamaan dengan asset reform-nya.

Adapun landasan yuridis pelaksanaan land reformdi Indonesia adalah UUPA. Khususnya pada Pasal 7 dan 17 tentang sumber pembatasan luas tanah maksimum. Ketentuan Pasal 10 diatur tentang larangan tanah absentee, dan Pasal 53 diatur tentang hak-hak sementara atas tanah pertanian. Peraturan perundang-undangandi bawahnya yang merupakan penjabaran dari ketentuan UndangUndang Republik Indonesia Nomor 56 tahun 1960 Tentang Penetapan Luas Tanah Pertanian, dijabarkan lebih lanjut di dalam Peraturan Pemerintah Nomor 224 Tahun 1961 dan Peraturan Pemerintah Nomor 41 Tahun 1964 tentang Pembagian Tanah dan Pemberian Ganti Rugi.

Kenyataan menunjukkan bahwa program land reformterlaksanarentan tahun 1961 sampai dengan tahun 1965 (Harsono, 1961). Perkembangan selanjutnya Pemerintahan Orede Baru tidak berjalan secara baik restruksturisasi pertanahan hanya dilaksanakan secara terbatas. Terbatas mengandung arti ingin dilepaskan keterkaitannya dengan konteks politis. Selama pemerintahan Orde Baru pelaksanaan land reform diimplementasikan dengan bentuk yang berbeda karena ada kerawanan sosial politik waktu itu.Program yang dilaksanakan waktu itu dengan meratakan persebaran penduduk untuk menguasai tanah yang belum dimanfaatkan untuk dimanfaatkan di dunia pertanian dengan program transmigrasi.
Sepanjang pemerintahan Orde Baru, land reform tidak pernah lagi diprogramkan secara terbuka, namun diganti dengan program pensertifikatan, transmigrasi, dan pengembangan Perkebunan Inti Rakyat (PIR), yang mempuyai tujuan adalah untuk memberikan kesempatan kepada rakyat mengelola dan memanfaatkan tanah. Jadi tidak dipandang dalam perspektif politis namun secara konkret atas dasar kebutuhan yang ada di dalam masyarakat. Perkembangan berikutnya, dewasa ini telah mengalami banyak perubahan terkait pembaharuan agraria inidalam peraturan perundangan-undangan terkait agraria. Melihat sisi yang berbeda tetap saja belum dijumpai program nyata tentan land reform di Indonesia sebagaimana telah diimplementasikan pada masa lalu.

Pelaksanaan land reform, hakekatnya memiliki berbagai persyaratan, antara lain:

a. Kesadaran dan kemauan dari elit politik

b. Organisasi petani dan masyarakat yang kuat

c. Ketersediaan data yang lengkap dan juga akurat

d. Dukungan anggaran yang memadai.

Berdasarkan faktor tersebut di atas merupakan gambaran masih lemahnya faktor tersebut sehingga pelaksanaan land reform secara nasional masih sulit terlaksana. Hal ini khususnya disebabkan adanya kondisi yaitu masih tidak sadaran elit politik mengenai pentingnya land reform dan kurang aktifnya peran serta pemerintah lokal. Pemerintah lokal dimaksud adalah Pemerintahan Daerah yang menskipun secdara yuridis mempunyai kewenaghan penuh dalam pengatyuran masalah pertanahan namun faktanya tetap masih dikendaikan secara terpusat.

Melihat sudut pandang prespektif administratif, untuk pola kebijakan pembuatan peraturan perundang-undangan yang mendukung kebijakan land reformdari kalangan politisi masih lemah. Hal tersebut hanya bisa dilihat hanya dalam Keputusan Presiden Republik Indonesia Nomor 131 Tahun 1961 yang kemudian disempurnakan dengan 


\section{Reformasi Agraria dalam Perspektif Perlindungan Lingkungan Hidup}

Samsul Wahidin

Keputusan Presiden Republik Indonesia Nomor. 263 Tahun 1964, sebagai pelaksanaan program Land reform dibentuk panitia yang menjalankan program land reform nasional. Dengan terbentuknya panitia land reform sebagai tolak ukur pada dasarnya pemerintah menaruh harapan terselesainya permasalahan land reform, namun pada kenyataannya masih terkesan sentralistik.

Perkembangan selanjutnya lahir Keputusan Presiden Republik Indonesia Nomor 55 Tahun 1980 tentang Organisasi dan Tata Kerja Penyelenggaraan Land reform, mengatur lebih lanjut keberadaan panitia land reformyang kemudian dibubarkan dan kewenangannya dimasukan dalam jajaran birokrasi Departemen Dalam Negeri, mulai dari menteri sampai dengan camat serta kepala desa. Hal tersebut menandakan bahwa program land reform hanya sebagian pekerjaan rutin belaka oleh pemerintah, namun masyarakat dan swasta untuk terlibat kurang jelas posisi dan perannya.

Permasalahan berikut yang sangat mendasar adalah adanya kenyataan yaitu kominitas masyarakat yang berprofesi sebagai petani tidak mempunyai kedudukan yang kuat dan terintgrasi. Dalam kaitan ini, manakala ditelusuri perkembangan keberadaan kelembagaan (atau adakalanya disebut organisasi) dalam masyarakat pertanian dan pedesaan, terlihat bahwa kelembagaan umumnya dibentuk dari atas, dan lebih sebagai wadah untuk distribusi bantuan dari pemerintah sekaligus untuk memudahkan pengontrolannya. Ribuan kelompok tani yang dibuat serta ditambah ribuan lagi koperasi, umumnya bukan berasal dari ide dan kebutuhan masyarakat setempat. Jenis kelembagaan seperti ini tentu bukan merupakan wadah perjuangan yang representatif untuk mengimplementasikan landrefrom, karena selain kondisi individualnya yang lemah, juga tidak terstruktur dan terintegrasi satu sama lain.

Perkembangan land reform di berbagai dunia terjadi pada era 1960-an dikarenakan menyesuaikan situasi politik dunia waktu itu. perkembangan land reform berkembang pesat setelah perang dunia ke dua karena dianggap sebgai sarana pembangunan dan permasalahan kemiskinan dan ketimpangan sosial. Saat itu negara-negara besar dan lembaga pendonor mendukung kebijakan tersebut. Sejalan dengan perkambangan waktu itu land reform tidak lagi mendapatkan perhatian karena tidak secara langsung berhubungan dengan peningkatan ekonomi.

Perspektif ini, berubah dewasa ini lembaga pendonor memfokuskan dirinya untuk mengimplementasikan program industrialisasi di negaranegara berkembang dibandingland reform. Kebijakn tersebut dipilih karena lebih dipandang membawa manfaat besar dan resiko lebih kecil. Bersamaan dengan itu, lahirnya revolusi hijau, semakin mengaburkan perhatian kepada land reform.

Indonesia sebagai negara kategori negara berkembang, sangat bergantung terhadap bantuan dari lembaga pendonor ataupun negara maju. hal tersebut merupakan salah satu penghambat pelaksanaan land reform di Indonesia karena dengan bantuan-bantuan dana dari negara dan lembaga asing tersebut justru bantuan itu digunakan sebagai tameng untuk mengontrol Indonesia untuk lebih fokus terhadap perkembangan dari dunia industri. Masa pemerintahan baru tidak memilih program land reform karena biayanya dan hasilnya belum tampak dalam jangka pendek. Sebaliknya tekanan arus ekonomi Kapitalis membuat tanah dijadikan komditas menarik investor asing untuk menanamkan modalnya, misalnya dengan regulasi dan dalam perkebunan-perkebunan swasta besar di bidang kelapa sawit yang tidak memperhatikan hak ulayat dan ekosistem alam.

Kondisi di atas secara langsung dipandang mendukung perekonomian Negara donor. Khususnya dalam hal penyediaan produk Agraria, khususnya perkebunan yang mendung kungkebutuhan negara donor untuk konsumsi rakyat Negara tersebut. Misalnyaproduk kelapa sawit yang kemudian booming, dan produk lain yang juga 
menjadi kebutuhan negara donor. Akibatnye tentu mau tidak mau negara penerima harus menurut, dengan meninggalkan masalah penataan keagrariaan kendatipun sebenarnya permasalahan ini lebih mendasar bagi masyarakat penerima donor.

\section{Simpulan}

Masalah keagrariaan merupakan satu di antarapermasalahan nasional yang sangat kompleks. Penyelesaian terhadap permasalahan tersebut cenderung berpacu dengan perubahan yang sangat pesat terahap berbagai permaaslahan yang menyertainya. Sementara penyelesaian yang dijadikan sebagai dasarnya harus merujuk pada aturan yang berkepastian hukum.Justru dalam permasalahan yang berkepastian hukum, seeringkali peraturan yangdisiapkan dan mulai diimplementasikan harus berpacu dengan waktu dan perubahan itu sendiri. Akibatnya berbagai peraturan yang ada dan dijadikan sebagai dasar hukum tertinggal oleh kenyataan yang ada dalam masyarakat. Khususnya yang berhubungan dengan permasalahan lingkungan hidup, justru orientasi dari Agraria nasional memerlukan pendekatan lebih komprehensif.

Di sini, urgensinya penataan yang harus dimulai dari awal, dengan menitikberatkan pada pola pikir masyarakat terhadap problema keagrariaan yang sangat kompleks dimaksud. Berbagai konsep penataan yangsudah ada, harus diuji kembali kesah hannya sebagai dasar pengelolaan keagrariaan. Dengan tindakan demikian diharapkan terjadi sinergitas antara masalah keagrariaan pada dengan keharusan orientasi pengelolaan yang berbasis lingkungan hidup.

\section{DAFTAR PUSTAKA}

Badan Pertanahan Nasional. 2007. Dokumen.Republik Indonesia. Jakarta.
Basya, Baihaqi. 2012. Redistribusi Lahan Di Cipari, Kabupaten Cilacap. Arc Books. Bandung.

Departemen Penerangan. 1962. Mimbar Penerangan.Volume 13. Jakarta.

Harsono, Budi. 1961. Undang-Undang Pokok Agraria, Sejarah Penyusunan Isi dan Pelaksanaannya. Jambatan.Jakarta.

Keputusan Presiden Republik Indonesia Nomor 55 Tahun 1980 tentang Organisasi dan Tata Kerja Penyelenggaraan Land reform. Jakarta.

Keraf, A.S. 2010. Etika Lingkungan Hidup. Penerbit Buku Kompas.Jakarta.

Peraturan Pemerintah Nomor 41 Tahun 1964 tentang Pembagian Tanah dan Pemberian Ganti Rugi. Jakarta.

Poerwadarminta, WJS. 2006. Kamus Umum Bahasa Indonesia. Jakarta: PN Balai Pustaka.

Risnarto, 2007. LandreformPlus di Indonesia. Bulletin LMPDP Media Pengembangan Kebijakan Pertanahan. Jakarta.

Siregar, Ali Rintop. 2012. Analisis Dampak Program Pembaruan Agraria Nasional (PPAN) Terhadap Pengembangan Wilayah Desa Perkerbunan Sei Balai Kecamatan Sei Balai Kabupaten Asahan. Tesis. Pascasarjana. Universitas Sumatera Utara. Medan.

Sumardjono, Maria W. 2014. Tanah dalam Perspektif Hak Ekonomi. Kompas. Jakarta.

TAP MPR IX/MPR/2001. Jakarta.

Undang-Undang Dasar Republik Indonesia Tahun 1945.

Undang-Undang Republik Indonesia Nomor 39 Tahun 1999 tentang Hak Asasi Manusia.Jakarta.

Undang-Undang Republik Indonesia Nomor 41 Tahun 1999 tentang Kehutanan. Jakarta.

Undang-Undang Republik Indonesia Nomor 5 Tahun 1960 tentang Pokok Agraria. Jarkarta.

Undang-Undang Republik Indonesia Nomor 56 tahun 1960 tentang Penetapan Luas Tanah Pertanian. Jakarta. 


\section{Reformasi Agraria dalam Perspektif Perlindungan Lingkungan Hidup}

Samsul Wahidin

Wahidin, Samsul. 2014. Dimensi Hukum Perlindungan \& Pengelolaan Lingkungan Hidup. Pustaka Pelajar. Yogyakarta.

Wahidin, Samsul.2016. Hukum Sumber Daya Air. Pustaka Pelajar.Yogyakarta.

\section{How to Cite:}

Wahidin, Samsul. 2017. Reformasi Agraria dalam Perspektif Perlindungan Lingkungan Hidup. Jurnal Cakrawala Hukum. 8 (1): 106-117. 